\title{
Model Performance Supported SMEs Strategy-Based Applications Through E-Money Gofood Business Customer Satisfaction and Grabfood
}

\author{
Novita Ekasari, Nurhasanah, Fitri Chairunnisa, Ade Perdana Siregar \\ Universitas Jambi, Jambi, Indonesia \\ Correspondence e-mail : ekasari.novita01@yahoo.com
}

\begin{abstract}
Advances in technology and modern lifestyle makes many emerging companies based financial technology (fintech), which offers various facilities through the application of e-based money where consumers are increasingly spoiled for culinary choice is especially promising business. This study aimed to determine the effect of the use of marketing strategies culinary SMEs belonging to the culinary application providers gofood and grabfood on its business performance through customer satisfaction service user business applications. Gofood and grabfood is a leading provider of Indonesia's biggest culinary applications so that users of these applications are very many in number. This study uses a sampling method in which samples used were 110 respondents business owners (business customers), which are small and medium businesses that have joined and cooperated with gofood and grabfood applications. This study has found that there is a direct or indirect effect of a positive and significant marketing strategy in which direct influence on the performance of SMEs has a percentage of 15.76\%, while the influence of marketing strategies on the performance of SMEs through business customer satisfaction by $11.46 \%$, while the influence overall $84.9 \%$. From the research, it is recommended businesses (SMEs) can be more creative in creating a product presentation, updating prices, and provide promotional package that is more diverse and this strategy was evaluated in a certain period of time, other than that businesses can utilize the features of merchant review to assess the results business in the eyes of end consumers and improve the brand image of their business.
\end{abstract}

Keywords : Business Performance; E-Money; Marketing Strategy; Customer Satisfaction.

\section{INTRODUCTION}

A few years many emerging companies based financial technology (fintech) which offers various facilities through application-based e-money. things into new business opportunities, especially for microenterprises, small and medium enterprises (SMEs) to expand the market at a cost that is not too high so as to expand the market through collaborations with the provider of the application. The problem often faced by SMEs such as less capable of doing promotion in a professional, unbiased expand the sales area, not literate in technology and a myriad of other problems can be solved through cooperation with application providers and digital payments that are expected to improve their business performance for many SMEs who have not received the maximum benefit from advances in digital technology are controlled by venture capital firms.

The purpose of this study was to see whether the use of marketing by using digital technology application has been carried out to the maximum by the micro, small and medium enterprises so as to improve its business performance. Among the providers of application services are much in demand in Indonesia is gofood and grabfoood providing booking feature food (culinary) where specifically in the provinces of Jambi number of SMEs Culinary according to labor offices and co-operatives have amounted to 4,634 units of the business which is largely a micro business and small capital up to 50 million rupiah so the chances of culinary products to evolve and gain a huge market for jambi city itself.

\section{Literature Review \\ Marketing strategy}

According to Kotler and Armstrong (2008), the definition of the marketing strategy is a marketing logic where the business unit hopes to create value and benefit from its relationship with the consumer. Tjiptono Fandy (2011: 40)formulate marketing mix be:

1. Product Is a form of organization offers services that are intended to achieve the objectives through the satisfaction of customer needs and desires. Products here can be anything (either physical tangible or not) which can be offered to potential customers to meet the needs and specific keingina. The products are all offered to the market for the note, obtained and used or consumed in order to fulfill the needs and desires be physical, services, people, organizations and ideas) 
2. Price, Mix price with respect to strategic and tactical policies such as price level, the structure of discounts, payment terms and the level of price discrimination between different groups of customers. Price describes the amount of rupiah that must be issued a consumer to obtain one product and should the price will be affordable for consumers.

3. Promotion promotion mix includes a variety of methods, namely advertising, sales promotion, face-toface sales, and public relations. Reflects the different way in which the company in order to sell products to consumers.

4. Place is a decision concerning the distribution of the ease of access to services for customers. The place where the products are available in a number of distribution channels

\section{Digital Payment (e-money)}

According Rival (2001) electronic money is a means to pay electronically obtained by depositing a first amount of money to the issuer, either directly, or through agents of the issuer, or by debiting an account at the Bank, and the value of the money is entered into the value of money in media electronic money, which is expressed in units of Rupiah, which is used to perform payment transactions by eliminating direct monetary value to the electronic money media. Payment cardnow evolved into e-money or commonly known as electronic money. Chip-based electronic money are typically published in bentuj cards issued by banks such as E-money, Tapcash, Brizzi, Flass, and so on. While the e-wallet server base such as T-cash, paypro, DOKU, Gopay. The difference between e-money and e-wallet balance lies in the maximum amount possible. But e-money and e-wallet is now very popular to make small-scale transactions for various types of payments and shopping at retail stores.

Micro, Small and Medium Enterprises (SMEs)

Criteria for SMEs According to Article 6 of the Law No. 20 of 2008 concerning the criteria for SMEs in the form of capital is as follows:

1. Criteria for Micro are as follows: i. have a net worth of at most Rp50,000,000.00 (fifty million rupiahs), excluding land and buildings; or ii. has annual sales results Rp300,000,000.00 (three hundred million rupiah).

2. Criteria for Small Business is as follows: i. have a net worth of more than Rp50,000,000.00 (fifty million rupiah) up to at most 500,000,000.00 (five hundred million rupiah) not including land and buildings

3. Criteria Medium Enterprises are as follows: i. have a net worth of more than Rp 500,000,000.00 (five hundred million rupiah) up to at most 10,000,000,000.00 (ten billion rupiahs), excluding land and buildings; or have an annual sales turnover of more than Rp2.500.000.000,00 (two billion five hundred million rupiah) up to at most Rp50.000.000.000,00 (fifty billion rupiah).

\section{Consumer Satisfaction}

According to Philip Kotler and Kevin Lane KellerConsumer satisfactionis feeling happy or disappointed someone who emerged after comparing the performance (yield) of the product thought to the expected performance (2007: 177).According to the theory in the journal Suwardi Kottler (2011), said that the key to retaining customers is customer satisfaction. Consumer satisfaction indicators can be seen from

1. Re-Purchased: Buy back, which the customer will return to the company to look for goods / services.

2. Creating word of mouth: in this case, pelnggan will say good things about the company to others.

3. Creating a Brand Image: Customers will pay less attention to the brand and advertising of competitors' products.

4. Creating a purchase decision in the same company: purchase another product from the same company.

\section{MSME performance}

Performance for Micro, Small and medium-sized enterprises (SMEs) According Munizu (2010) the performance of small and medium enterprises can be measured by the following indicators: The rapid growth of sales, growth capital, The growth of labor, market growth, Profit growth. 


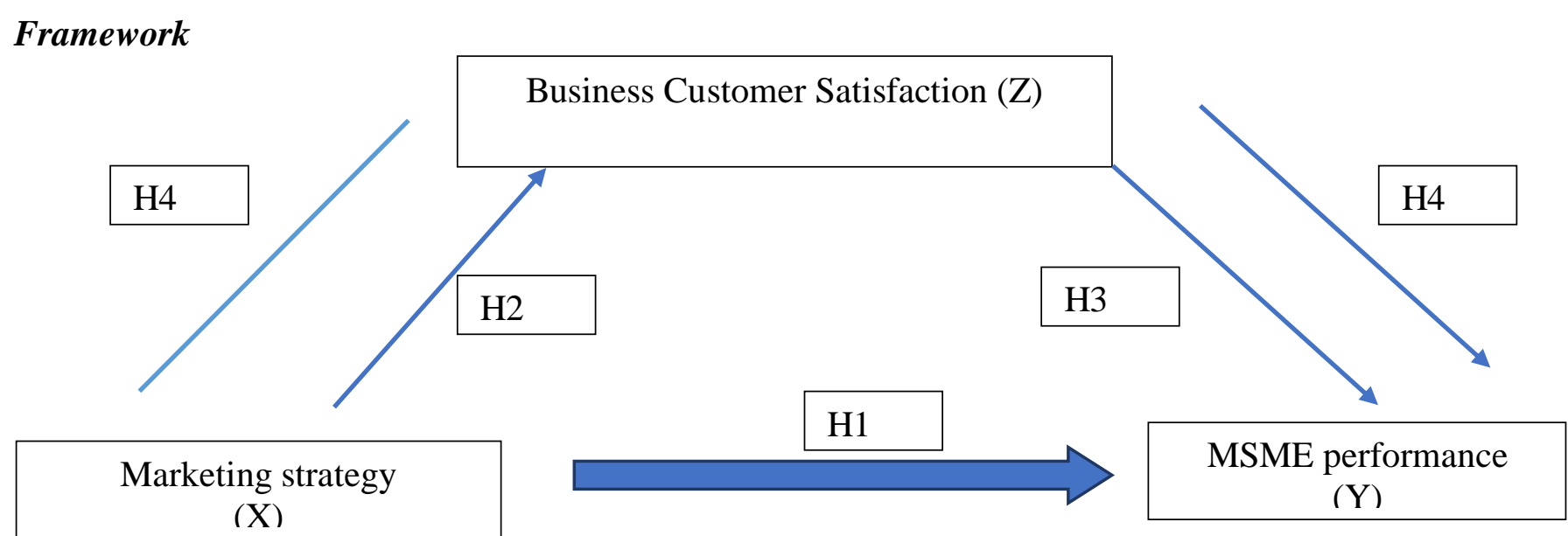

\section{METHOD}

The data source is anything that can provide information on data. Based on the source, the data can be divided into two, namely primary data and secondary data.

1. Primary data is data created by researchers for the special purpose of solving the problems that are being handled. The data were collected by researcher directly from the first source or object where research is conducted.

2. Secondary data is data that has been collected for purposes other than to solve the problem at hand. This data can be found quickly. In this study, the secondary data source is literature, articles, journals and websites on the internet with regard to the research conducted.

\section{Operationalization of Research Variables}

The operational definition describes a particular method that is used by researchers to operationalize the construct, thus allowing other researchers to conduct repeatability of measurements in the same way or trying to distribute construct a better measurement. In this study, the operational definition outlined in the following table:

Table 1

Operationalization Variables

\begin{tabular}{|c|c|c|c|c|}
\hline No. & Variable/Sub variables & variable concept & Indicator & scale Ruler \\
\hline 1 & Customer Satisfaction (Z) & $\begin{array}{l}\text { feeling happy or disappointed } \\
\text { someone who emerged after } \\
\text { comparing the performance (yield) of } \\
\text { the product thought to the expected } \\
\text { performance }\end{array}$ & $\begin{array}{ll}- & \text { Re-Purchase } \\
\text { - } & \text { Creating word of mouth } \\
\text { - } & \text { Creating a brand image } \\
- & \text { Purchasing decisions } \\
& \text { (application usage) }\end{array}$ & ordinal \\
\hline 2 & Marketing strategy (X) & $\begin{array}{l}\text { Logic Marketing where business } \\
\text { units expect to create value and } \\
\text { benefit from the relationship with the } \\
\text { consumer }\end{array}$ & $\begin{array}{l}\text { - } \text { product } \\
\text { - Price } \\
\text { - } \text { Place } \\
\text { - } \text { Promotion }\end{array}$ & ordinal \\
\hline 3 & Performance of SMEs (Y) & $\begin{array}{l}\text { is a function of the interaction } \\
\text { between ability or abilities }(\mathrm{A}) \text {, } \\
\text { motivation }(\mathrm{M}) \text { and the chance or } \\
\text { opportunity }(\mathrm{O}) \text { that can be expressed } \\
\text { in the formula of performance = } \mathrm{f}(\mathrm{A} \\
\mathrm{x} \mathrm{M} \times \mathrm{O}) \text {, meaning that performance } \\
\text { is a function of ability, motivation } \\
\text { and opportunity. }\end{array}$ & $\begin{array}{ll}\text { - } & \text { sales growth } \\
\text { - } & \text { growth Capital } \\
\text { - } & \text { Employment growth } \\
\text { - } & \text { Market growth } \\
\text { - } & \text { Profit growth }\end{array}$ & ordinal \\
\hline
\end{tabular}

a. Population and Sample

In this study, researcher use the non probability sampling method with convenience sample to the reacheable population around jambi area. the population of business customers (SMEs) application users Gojek (gofood) and Grab (grabfood) specialized in Jambi unknown number with certainty, so that the 
sample used in the formula Hair et al., (2010) that the determination of the number of samples in accordance with the large number of items indicator assuming $\mathrm{n} \times 5$ to 10 observations. In this study the authors used $\mathrm{n} \times 8$ so that the sample size is not too small of which $13 \times 8=104$ respondents, which is rounded to 110 respondents .

b. Data analysis method

In this research using descriptive analysis. Descriptive analysis is used to describe the study variables, namely marketing strategy, customer satisfaction business (merchant) and the performance of SMEs descriptive analysis performed to establish a table of frequency distribution to determine whether the rate of value (score) variables studied into theExcellent category / very high, good / high, fairly good / high enough, not good / low, and is not very good / very low. Further analysis tool used is multiple linear regression analysis and path analysis (path analysis).

\section{FINDINGS}

\section{characteristics of Respondents}

This study analyzed the influence of marketing strategies using e-money applications based on the performance of SMEs culinary business customer satisfaction as an intervening variable in Culinary SMEs in cooperation with food go and grab food in the city of Jambi. The number of samples in this research were 110 respondents owner culinary specialty SMEs in cooperation with the applications go grab food in the food and culinary products penjulan online. While the distribution characteristics of the respondents can be seen in the following table:

Table 2

Distribution Characteristics of Respondents Table Research

\begin{tabular}{|c|c|c|c|c|c|}
\hline \multicolumn{2}{|c|}{ respondent characteristic } & \multicolumn{2}{|c|}{ Frequency } & Percentage & \multirow[t]{2}{*}{ Total } \\
\hline Sex & Male & 60 & & $54.5 \%$ & \\
\hline & Female & 50 & & $45.5 \%$ & \\
\hline & & \multicolumn{3}{|c|}{110} & $100 \%$ \\
\hline \multirow{5}{*}{ Age } & $<20$ years old & 10 & & $9.1 \%$ & \\
\hline & 20-30 years old & 60 & & $54.5 \%$ & \\
\hline & $31-40$ years old & 23 & & $21 \%$ & \\
\hline & $>40$ years old & 17 & & $15.4 \%$ & \\
\hline & & \multicolumn{3}{|c|}{110} & $100 \%$ \\
\hline \multirow[t]{5}{*}{ owned Business } & $<1$ year & 37 & & $33.6 \%$ & \\
\hline & $1-2$ year & 43 & & $39.1 \%$ & \\
\hline & 2 year 1 day-3 year & 8 & & $7.3 \%$ & \\
\hline & $>3$ year & 22 & & $20 \%$ & \\
\hline & & & 110 & & $100 \%$ \\
\hline \multirow[t]{4}{*}{ Applications used } & Gofood & 29 & & $26.3 \%$ & \\
\hline & Grabfood & 40 & & $36.4 \%$ & \\
\hline & Gofood and grabfood & 41 & & $37.3 \%$ & \\
\hline & & & 110 & & $100 \%$ \\
\hline \multirow{5}{*}{ Length of cooperation } & $<1$ year & 64 & & $58.2 \%$ & \\
\hline & $1-2$ year & 41 & & $37.3 \%$ & \\
\hline & 2 year 1 day-3 year & 4 & & $3.6 \%$ & \\
\hline & $>3$ year & 1 & & $0.9 \%$ & \\
\hline & & & 110 & & $100 \%$ \\
\hline
\end{tabular}

\section{Results}

To get a picture of variable marketing strategy (x), Consumer satisfaction (Z) and MSME Performance $(\mathrm{Y})$, then it can be explained in the form of descriptive results of the frequency distribution table as follows: 
Table 3

Respondents Regarding tabulation Marketing strategy, customer satisfaction and performance of SMEs

\begin{tabular}{|c|c|c|c|c|c|}
\hline No. & Indicator & $\mathbf{N}$ & Min & Max & mean \\
\hline & Marketing strategy & & & & \\
\hline 1. & Being able to sell more product variants & 110 & 2 & 5 & 3.86 \\
\hline 2. & $\begin{array}{l}\text { Prices were sold through the application of a higher } \\
\text { refractive }\end{array}$ & 110 & 1 & 5 & 3.15 \\
\hline 3. & Wider range of sales & 110 & 2 & 5 & 4.07 \\
\hline 4. & More widely known business brand & 110 & 3 & 5 & 4.34 \\
\hline \multirow[t]{2}{*}{ Total } & & & & & 3.85 \\
\hline & Consumer satisfaction & & & & \\
\hline 5 & Repurchase & 110 & 2 & 5 & 4.03 \\
\hline 6 & WOM among consumers & 110 & 2 & 5 & 3.96 \\
\hline 7 & Business brand is known more positive & 110 & 3 & 5 & 4.07 \\
\hline 8 & Continue to work with application providers & 110 & 3 & 5 & 4.12 \\
\hline \multirow[t]{2}{*}{ Total } & & & & & 4,05 \\
\hline & MSME performance & & & & \\
\hline 9 & The sales volume is increasing & 110 & 2 & 5 & 3.90 \\
\hline 10 & The sales turnover increased & 110 & 2 & 5 & 3.81 \\
\hline 11 & Be able to hire more employees & 110 & 2 & 5 & 3.23 \\
\hline 12 & Greater profit & 110 & 2 & 5 & 3.65 \\
\hline Total & & & & & 3.64 \\
\hline
\end{tabular}

\section{Regression analysis}

Regression analysis was used to determine how much variable effect on other variables. In this case, the equation that can be used are: $\mathrm{Y}=\mathrm{a}+\mathrm{b} 1 \mathrm{X}+\mathrm{e}$ following simple linear regression test results are presented in the table below:

Table 4

Coefficients

\begin{tabular}{|c|c|c|c|c|c|c|}
\hline \multicolumn{7}{|c|}{ Coefficientsa } \\
\hline \multirow{4}{*}{$\begin{array}{l}\text { Model } \\
1\end{array}$} & & Coefficients u & tandardi zed & $\begin{array}{l}\text { standardized } \\
\text { Coefficients }\end{array}$ & & \\
\hline & & & Std. Error & beta & & Sig. \\
\hline & (Constant) & 1,498 &, 419 & & 3.577 & .001 \\
\hline & X1 & .543 & 121 & .397 & 4.499 &, $\mathrm{OOO}$ \\
\hline
\end{tabular}

\begin{tabular}{|c|c|c|c|c|c|c|}
\hline \multicolumn{7}{|c|}{ Coefficientsa } \\
\hline \multirow[b]{2}{*}{$\begin{array}{l}\text { Model } \\
1\end{array}$} & \multirow[b]{2}{*}{$\begin{array}{l}\text { (Constant) } \\
Z\end{array}$} & \multicolumn{2}{|c|}{ Coefficients unstandardized } & $\begin{array}{l}\text { standardized } \\
\text { Coeffi cients }\end{array}$ & \multirow[b]{2}{*}{$\begin{array}{l}\text { t } \\
6.266 \\
6.473\end{array}$} & \multirow[b]{2}{*}{$\begin{array}{l}\text { Sig. } \\
\text {,OOO } \\
\text {,OOO }\end{array}$} \\
\hline & & $\begin{array}{r}\text { B } \\
1,674 \\
, 545\end{array}$ & $\begin{array}{r}\text { Std. Error } \\
, 267 \\
, 084\end{array}$ & beta & & \\
\hline
\end{tabular}

Sumber: data olahan

From the table above can be obtained by the equation:

$\mathrm{Y}=1,498+0,543 \mathrm{X}+\mathrm{e}$

so that it can be interpreted as follows:

1. Constants worth 1,496 shows that if variable marketing strategy $(\mathrm{X})$ is 0 then it can raise SMEs performance variable (Y) of 1,496.

2. The regression coefficient marketing strategy $(\mathrm{X})$ of 0.543 is positive on the performance of SMEs. This indicates that any value variable marketing strategy promoted one unit, then the variable performance of SMEs will increase by 0.543 .

$\mathrm{Y}=1.674+0,545 \mathrm{Z}+\mathrm{e}$

So it can be interpreted as follows:

1. Constants worth 1.674 indicates that if variable customer satisfaction $(Z)$ is 0 , it can increase the performance of SMEs variable (Y) of 1,674. 
2. The regression coefficient business customer satisfaction $(\mathrm{Z})$ of 0.545 is positive on the performance of SMEs. This shows that every business customer satisfaction variable value increase by one unit, then the variable performance of SMEs will increase by 0.545 .

\section{The coefficient of determination (R2)}

Analysis of the coefficient of determination adjusted and used to determine how large a percentage of the independent variable $(\mathrm{X})$ to the dependent $(\mathrm{Y})$ in the form of a percentage. Here is the coefficient of determination test results are presented in the table below:

Table 5

Model Summaryb

\begin{tabular}{|c|c|c|c|c|c|c|c|c|c|c|}
\hline \multirow[b]{2}{*}{ Model } & \multirow[b]{2}{*}{$\mathrm{R}$} & \multirow[b]{2}{*}{ R Square } & \multirow[b]{2}{*}{$\begin{array}{l}\text { Adjusted } \\
\text { R Square }\end{array}$} & \multirow[b]{2}{*}{$\begin{array}{l}\text { Std. Error of } \\
\text { the Estimate }\end{array}$} & \multicolumn{5}{|c|}{ Change Statistics } & \multirow[b]{2}{*}{$\begin{array}{l}\text { Durbin- } \\
\text { Watson }\end{array}$} \\
\hline & & & & & $\begin{array}{l}\text { R Square } \\
\text { Change }\end{array}$ & $\begin{array}{c}\text { F } \\
\text { Change }\end{array}$ & DF1 & DF2 & $\begin{array}{l}\text { Sig. F } \\
\text { Change }\end{array}$ & \\
\hline 1 &, $397 \mathrm{a}$ &, 158 &, 150 &, 67134 &, 158 & 20.238 & 1 & 108 &, 000 & 1.685 \\
\hline
\end{tabular}

Sumber: data olahan

According to the table above figures obtained Adjusted R Square of 0.150. This shows the influence of marketing strategies simultaneously to affect the performance of SMEs by $15 \%$ while the remaining $85 \%$ are influenced or explained by other variables not included in this research model.

\section{Hypothesis Testing}

\section{First Hypothesis (H1)}

$\mathbf{H}_{1}: \mathbf{X} \rightarrow \mathbf{Y}$ The first hypothesis (H1) that is partially significant $\mathrm{X}$ to $\mathrm{Y}$.

Table 6

Test t

\begin{tabular}{|c|c|c|c|c|c|c|}
\hline \multirow{2}{*}{\multicolumn{2}{|c|}{ Model }} & \multicolumn{2}{|c|}{ Coefficients unstandardized } & \multirow{2}{*}{$\frac{\text { Standardized Coefficients }}{\text { beta }}$} & \multirow[b]{2}{*}{$\mathrm{t}$} & \multirow[b]{2}{*}{ Sig. } \\
\hline & & $\mathrm{B}$ & Std. Error & & & \\
\hline \multirow[t]{2}{*}{1} & (Constant) & 1,498 & , 419 & & 3.577 & .001 \\
\hline & $\mathrm{X} 1$ &, 543 & 121 & 397 & 4.499 &, 000 \\
\hline
\end{tabular}

Sumber: data olahan

As shown on test result table, the influence of marketing strategy (X) partially significant to the performance of SMEs (Z) with percentage by $39,7 \%$.

\section{Second Hypothesis (H2)}

$\mathbf{H}_{2}: \mathbf{X} \rightarrow \mathbf{Z}$ The second hypothesis (H2) that $\mathrm{X}$ is partially significant effect on $\mathrm{Z}$.

Table 7

Test t

\begin{tabular}{|c|c|c|c|c|c|c|}
\hline \multirow{2}{*}{\multicolumn{2}{|c|}{ Model }} & \multicolumn{2}{|c|}{ Coefficients unstandardized } & \multirow{2}{*}{$\begin{array}{c}\text { Standardized Coefficients } \\
\text { beta } \\
\end{array}$} & \multirow[b]{2}{*}{$\mathrm{t}$} & \multirow[b]{2}{*}{ Sig. } \\
\hline & & $\mathrm{B}$ & Std. Error & & & \\
\hline \multirow[t]{2}{*}{1} & (Constant) & 618 & 371 & & 1.664 &, 099 \\
\hline & $\mathrm{X} 1$ & 723 & 107 & 545 & 6.748 &, 000 \\
\hline
\end{tabular}

Sumber: data olahan

As shown on test result table, the influence of marketing strategy (X) partially significant to the Customer Satisfaction (Z) with percentage by $54,5 \%$.

\section{H3: Z $\rightarrow$ Y}

The third hypothesis (H3) that $\mathrm{Z}$ is partially significant effect on $\mathrm{Y}$. 
Table 8

Test $\mathrm{t}$

\begin{tabular}{|c|c|c|c|c|c|c|}
\hline \multirow{2}{*}{\multicolumn{2}{|c|}{ Model }} & \multicolumn{2}{|c|}{ Coefficients unstandardized } & \multirow{2}{*}{$\begin{array}{c}\text { Standardized Coefficients } \\
\text { beta }\end{array}$} & \multirow[b]{2}{*}{$\mathrm{t}$} & \multirow[b]{2}{*}{ Sig. } \\
\hline & & $\mathrm{B}$ & Std. Error & & & \\
\hline \multirow[t]{2}{*}{1} & (Constant) & 1,674 &, 267 & & 6.266 &, 000 \\
\hline & $\mathrm{X} 1$ &, 545 & 084 & 529 & 6.473 &, 000 \\
\hline
\end{tabular}

Sumber: data olahan

As shown on test result table, the influence of Customer Satisfaction (Z) partially significant to the performance of SMEs (Y) with percentage by 52,9\%.

\section{Fourth Hypothesis (H4)}

$\mathrm{H}_{4}: \mathrm{X} \Omega \mathrm{Z} \rightarrow \mathrm{Y}$

The fourth hypothesis (H4) that $\mathrm{X}$ through $\mathrm{Z}$ simultaneously significant effect on $\mathrm{Y}$.

Table 9

Annova

\begin{tabular}{|l|r|r|r|r|r|}
\hline Model & Sum of Squares & df & mean Square & F & Sig. \\
\hline 1 Regression & 17.136 & 2 & 8.568 & 22.548 & \\
residual & 40.660 & 107 &, 380 & & \\
Total & 57.796 & 109 & & & \\
\hline
\end{tabular}

Sumber: data olahan

\section{Variable Path Analysis Research}

Effect of $X$ on $Y$

$\mathrm{X} \rightarrow \mathrm{Y}$ is Pyx.Pyx $=(0.397)(0.397)=0.157609$ or rounded $15.76 \%$

Effect of $X$ on $Z$

$\mathrm{X} \rightarrow \mathrm{Z}$ is Pzx.Pzx $=(0.545)(0.545)=0.297025$ or rounded $29.70 \%$

So that the effect of $Z \rightarrow Y$ is Pzy.Pzy $=(0.529)(0.529)=0.279841$ or rounded $27.98 \%$.

Effect of $X$ on $Y$ through $Z$

Effect of $\mathrm{X}$ on $\mathrm{Y}$ by $\mathrm{Z}$ :

$X \rightarrow \Omega$ Y Z $=$ Pyx.Pzx.Pzy $=(0.397)(0.545)(0.529)=0.114457=11.46 \%$

So it can be concluded that there are significant marketing strategies on the performance of SMEs through business customer satisfaction $(\mathrm{Z})$ of 0.114457 , or $11.46 \%$.

Table 10

Interpretation summary

\begin{tabular}{clcc}
\hline No. & & Information & $\%$ \\
\hline 1 & Effect of X on Y & 15.76 \\
2 & Effect of X on Z & 29.70 \\
3 & Effect of Z on Y & 27.98 \\
4 & Effect of X on Y through Z & 11.46 & - \\
& The total effect of study variables & - & 84.9 \\
& The total effect of other variables & & 15.1 \\
& Total & & 100 \\
\hline
\end{tabular}

Sumber: data olahan

\section{DISCUSSIONS AND RECOMMENDATIONS}

The development of electronic technology is a challenge for businesses, especially the micro, small and medium enterprises (SMEs) so as to be able to adjust the marketing strategy that has been done conventionally with offline sales is becoming more up to date by opening to the technological advances of sales (selling) by using the online sales application that is more convenient to use by this customer, analyze the impact of marketing strategies used by SMEs culinary to the performance of SMEs after using the application of sales go grab food and food through customer satisfaction business enterprises (SMEs). The 
results showed the interrelations between variables with the conceptual framework of research as evidenced from the results of several models that significant matches. Based on the results of the study shows that the marketing strategy has a higher impact on the performance of SMEs directly in the amount of $15.76 \%$ compared with the mediation variable customer satisfaction business that only has the effect of $11.46 \%$. This shows that satisfied or absence of business consumers on the performance of the application is not too improve business performance (profit, turnover, etc.), this is in line with research conducted by Dita mandate (2015) which states that businesses must always evaluate marketing mix in order to get periodically for optimal results. The results also show that most influence is shown by the decision of a marketing strategy using business applications to consumer satisfaction with $29.70 \%$ of influence, so that it can be concluded that the service providers can join the application is able to provide satisfaction was high for small micro business and intermediate. This is reinforced by research Amalia Suri, et al (2016), which explains that the marketing mix consisting of product, price, place and promotion significantly influence the customer satisfaction of $41.7 \%$. While the business customer satisfaction were considered to improve business performance with a yield of $27.98 \%$. So we can conclude that a marketing strategy can improve business performance of SMEs either directly or indirectly through business customer satisfaction $84.9 \%$ while the remaining $15.1 \%$ is explained by other variables that are not included in this study.

\section{Recommendations}

1. The food vendors online (businesses)should be more active in making marketing through renewed marketing strategy in order to attract consumer appeal. Such as by providing attractive promo when thereevent in a given month (example: Christmas and New Year). Gives a good picture of food products to appeal to appeal to consumers. And food vendorson line should be more creative in providing packages for consumers.

2. Utilizing the features merchant review that will be issued by the application so that the merchant obtain a high rating and be able to increase the number of sales, a reference merchant for the end consumer to create and make the brand enterprises become more widely known.

\section{REFERENCES}

Adityawarman. Jasa Marga 2014. Difficulties Prepare Money Refund.https://goo.gl/GN7fMo, 2016 Buchari, Alma, 2009, Marketing Management and Marketing Services, Molds eighth, Bandung: Alfabeta.

Dita Amanah. 2015. Influence of Marketing Mix on Performance of Small and Medium Enterprises (SMEs). Journal of Community Service Vol 21 No. 81Tahun XXI September 2015.

Fanny Octaria Zuari, Hapsari Widayani, Raycard D. 2013. Influence Marketing Strategies Against Net Revenue Omah pincuk. Proceeding PESAT Volume 5 October 2013, Bandung.

Idrus, M (2009). Social Science Research Methods. Yogyakarta. PT.Gelora Script Primary.

Kotler, Philip and Gary Armstrong (2008). Principles of Marketing. 13. Issue Volume 1. Jakarta: Erland.

Musran Munizu (2010). Influence Factors and Performance Against Internal Micro and Small Enterprises (MSEs) in South Sulawesi, Journal of Management and Entrepreneurship, Vol 12, No.1, March 2010: 33-41.

Noe, Hollenbeck, Gerhart, Wright. 2003. Human Resource Management, International edition. New York: McGraw-hill Compan

Rival, V., et., Al. 2001. Banks and Financial Institution Management. Jakarta: PT. King Grafindo Persada Tjiptono, Fandy. 2009.,Marketing strategy, Yogyakarta: Andi.

Ramdani, A., 2015. Against Separation Policy Influence Profits at Bank BNI Syariah. journal Etikonomi, 14 (1).

Robbins, Stephen P. 2001. Organizational Behavior: Concepts, Controversies, Applications, Volume 1, Issue 8, Prenhallindo, Jakarta.

Suwardi. 2011.Towards the Creation of Customer Satisfaction Through Quality of Service, State Polytechnic of Semarang. 